\title{
Acetate acts as a protonophore and differentially affects bead movement and cell migration of the gliding bacterium Cytophaga johnsonae (Flavobacterium johnsoniae)
}

\author{
JoAnn L. Dzink-Fox, Edward R. Leadbetter and Walter Godchaux, III
}

Author for correspondence: Edward R. Leadbetter. Tel: +1 860486 5398. Fax: +1 8604861936. e-mail : erl@uconnvm.uconn.edu

Department of Molecular and Cell Biology, University of Connecticut, Storrs, CT 06269-2131, USA
Cells of Cytophaga johnsonae (now Flavobacterium johnsoniae) are able to translocate on solid surfaces but are unable to swim in liquid media.

Organelles that may be involved in this gliding motility have not been detected, and the mechanism(s) responsible remains unknown. The movement of latex beads attached to the cell surface is considered by some to be a manifestation of the gliding machinery. In this study, acetate (in nutrient-level quantity, $45 \mathrm{mM}$ ) was found to inhibit bead movement on cell surfaces, whilst formation and movement of groups of cells (rafts) and typical colony spread were not affected; generation time (in liquid culture) was only slightly increased. Since acetate is a weak acid and is recognized as a protonophore, various electron-transport-associated features were assessed in an effort to understand the differential effects of acetate on bead movement and cell motility. Selected protonophores and electron transport inhibitors were tested to compare their effects on cell translocation and metabolic activities with those of acetate. Although $\mathrm{O}_{2}$ consumption was not significantly affected in the presence of acetate and the protonmotive force decreased only minimally, ATP levels were markedly decreased. Arsenate and cyanide were also shown to inhibit bead movement but did not inhibit either movement of rafts of cells or colony spreading. Cyanide lowered $\mathrm{O}_{2}$ consumption, while arsenate did not; both compounds effected substantial decreases in cellular ATP content, but little or no decrease in protonmotive force. The inhibitory effects of these compounds on bead movement over cell surfaces contrasted with the continued ability of cells to form rafts, to glide and to form spreading colonies and led to the conclusion that bead movement is not a complete correlate of the gliding machinery of $C$. johnsonae. In addition, it seems likely that bead movement is more affected by the level of cellular ATP than it is by the protonmotive force, which has been assumed to provide the energy (derived from the transmembrane gradients) for the gliding machinery.

Keywords: bead movement, gliding motility, Cytophaga jobnsonae (Flavobacterium jobnsoniae), protonmotive force

\section{INTRODUCTION}

The gliding motility of the cytophagas is characterized by the ability of these fusiform Gram-negative cells to

Abbreviations: $C C C P$, carbonyl cyanide $m$-chlorophenylhyrazone; DCCD, dicyclohexylcarbodiimide; FCCP, carbonyl cyanide $p$-(trifluoromethoxy)phenylhydrazone; PMS, phenazine methosulfate; $\mathrm{TPP}^{+}$, tetra $\left[{ }^{3} \mathrm{H}\right]$ phenylphosphonium bromide. translocate over a solid surface to form thin colonies with feathery, finger-like edges. Gliding motility requires cell contact with a solid surface or an air-water interface (Weibull, 1960); when placed in a liquid medium, cells are non-motile. To date, no recognizable organelles of motility have been found that might account for cell movement and the mechanisms responsible remain unknown. The sole known molecular correlate of gliding motility is the presence of unusual outer mem- 
brane components - sulfonolipids - characteristic of the Cytophaga-Flexibacter group (Abbanat et al., 1986; Godchaux \& Leadbetter, 1983). These lipids, as well as the ornithine amino lipids, also present in significant quantities (Pitta et al., 1989), are characterized by large amounts of branched-chain fatty acyl moieties. In addition to the cytophagas (Walker, 1968), an unrelated group of gliding bacteria (the myxobacters) also contain especially large amounts of branched-chain fatty acids (Ware \& Dworkin, 1973).

Since an increased content of branched-chain fatty acids is considered to increase membrane fluidity and it has long been argued that greater membrane fluidity could be a salient trait of gliding bacteria (Nichols et al., 1986), the large amounts of these compounds may be important for this ability to move over solid surfaces. In one experiment to assess the influence of branched-chain fatty acid content on the ability of Cytophaga johnsonae (now Flavobacterium johnsoniae) cells to glide, we supplied acetate, in nutrient-level concentrations in a carbon-limited medium in an effort to induce an alteration in the fatty acid composition of membrane lipids from branched- to straight-chain species. Although no significant differences in the profile of cellular fatty acids were found, a trait presumed to be a significant marker of gliding motility - the ability to move latex spheres over cell surfaces - was affected.

Pate \& Chang (1979) and Lapidus \& Berg (1982) first observed the movement of such microspheres over the surface of gliding bacteria and suggested that it was a manifestation of the gliding machinery presumed present in the cell envelope. This putative relationship of bead movement to gliding ability has however been questioned by us and others because of contradictory observations (Ridgway \& Lewin, 1988; Gorski et al., 1991). As the present study reveals, cells grown in or on media containing acetate at concentrations from 35 to $50 \mathrm{mM}$ failed to move attached beads over their surfaces, while colony enlargement (spreading), which is a result of cell migration on the agar surface, was normal.

Acetate, which does not serve as sole source of carbon and energy for growth of C. johnsonae, is recognized to dissipate the proton gradient in other bacteria that have been examined. It seemed possible then, that acetate might be acting in a similar manner in this bacterium and so lead to a decrease in the energy supply of the cells. The protonmotive force is regarded as the source of energy for gliding (and, presumably, bead movement) (Duxbury et al., 1980; Pate \& Chang, 1979; Ridgway, 1977; Wolkin \& Pate, 1986). If the effects of acetate were a result of diminishing the electrochemical gradient of protons across the membrane, the ability of cells to glide (and colonies to spread) could be affected. Accordingly, we examined the effects of acetate and selected inhibitors of electron transport and oxidative phosphorylation on various energy-related activities that might influence gliding of C. johnsonae. We report here results of these studies on colony spreading, raft formation and movement, and bead movement, as well as $\mathrm{O}_{2}$ consumption,
ATP levels, and proton gradient and membrane potential (together constituting the protonmotive force).

\section{METHODS}

Bacterial strains and growth conditions. Studies were performed with C. jobnsonae (ATCC 43786). Escherichia coli $\mathrm{K}-12$ was also used for comparison, when appropriate. The growth medium [a modified EC (enriched cytophaga) medium; Pate \& Ordal, 1967] contained 3.5 g tryptone and $0.75 \mathrm{~g}$ yeast extract per litre, and was adjusted to $\mathrm{pH} 7.4$ before autoclaving; for solid media, $1.8 \%$ (w/v) Bacto agar was added. Overnight cultures were grown aerobically to lateexponential phase $\left(\mathrm{OD}_{650} 0 \cdot 8\right.$; Cary model 219 spectrophotometer; $1 \mathrm{~cm}$ light pathlength) in a waterbath-shaker at 80 r.p.m. at $25^{\circ} \mathrm{C}\left(37^{\circ} \mathrm{C}\right.$ for E. coli $)$ and used as inoculum for each study. Cells were harvested in early- to mid-exponential phase (unless otherwise indicated), depending upon the assay to be performed.

Chemicals. Carbonyl cyanide $m$-chlorophenylhydrazone (CCCP), carbonyl cyanide $p$-(trifluoromethoxy)phenylhydrazone (FCCP), dicyclohexylcarbodiimide (DCCD), DNP, valinomycin, nigericin, sodium ascorbate, phenazine methosulfate (PMS), sodium azide, sodium arsenate, luciferinluciferase assay kit (FL-AAM, FL-AAB) and ATP were from Sigma. Sodium acetate and sodium cyanide were from Fisher Scientific. $\left[7-{ }^{14} \mathrm{C}\right]$ Benzoic acid $\left(40 \mathrm{mCi} \mathrm{mmol}^{-1}, 1.5 \mathrm{GBq}\right.$ $\left.\mathrm{mmol}^{-1}\right)$ and $\left[\mathrm{U}^{14} \mathrm{C}\right]$ sucrose $\left(530 \mathrm{mCi} \mathrm{mmol}^{-1}, 20 \mathrm{GBq}\right.$ mmol $^{-1}$ ) were from ICN Biomedicals. Tritiated $\mathrm{H}_{2} \mathrm{O}$ was from Amersham; [carboxyl- $\left.{ }^{14} \mathrm{C}\right]$ inulin $(0.05 \mathrm{mCi}, 1.9 \mathrm{MBq})$ and tetra $\left[{ }^{3} \mathrm{H}\right]$ phenylphosphonium bromide $\left(\mathrm{TPP}^{+}\right)\left(37 \mathrm{Ci} \mathrm{mmol}^{-1}\right.$; $1.4 \mathrm{TBq} \mathrm{mmol}^{-1}$ ) were from Dupont-New England Nuclear.

Colony spreading. C. jobnsonae was grown to mid-exponential phase $\left(\mathrm{OD}_{650} 0.4\right)$ and diluted in fresh sterile medium to obtain a few, spatially separated colonies when plated on agar containing a range of concentrations of the various additives (Table 1) and a control without additives. After incubation for up to $3 \mathrm{~d}$, colony type (spreading or not spreading) was noted. The highest concentration of additive that still permitted growth (Table 1) was chosen for additional evaluations of bead and cell movement.

Movement of latex spheres by cells. An overnight culture of C. jobnsonae was inoculated into fresh broth and incubated until an $\mathrm{OD}_{650}$ of $0 \cdot 1-0 \cdot 2$ was attained. At that time, aliquots of the culture were placed into separate flasks, allowed to equilibrate for a few minutes and the appropriate concentration of inhibitor (Table 1) was then added to each flask. Duplicate samples were removed at designated times to determine optical density and bead movement. A suspension of polystyrene latex beads $(0.261 \mu \mathrm{m}$; Seragen Diagnostics) was added to the duplicate samples to a density of approximately 50 beads per cell as described by Pate \& Chang (1979) and modified by Godchaux et al. (1990). Bead movement on the cell surface was immediately assessed in wet mounts for 2-3 min by phase-contrast microscopy at a total magnification of $\times 400$ and scored as either positive or negative. Longer observation times evidently rendered a wet mount anoxic, resulting in the cessation of bead movement on control cells.

Raft formation and movement by cells. The ability of cell populations to form rafts was determined as described previously (Godchaux et al., 1991). For the inhibitor studies, aliquots of liquid cultures $\left(\mathrm{OD}_{650} 0 \cdot 7-0.8\right)$ were placed in flasks to which the test agents were added and incubated for various times up to $30 \mathrm{~min}$. Cells were centrifuged and resuspended in non-nutrient buffer (10 mM HEPES, $1 \mathrm{mM} \mathrm{MgCl}_{2}, 1 \mathrm{mM}$ $\mathrm{CaCl}_{2}$ ) to an approximate $\mathrm{OD}_{650}$ of 1.5 . It was important to 
use a dense suspension of cells to produce large, moving rafts. Droplets $(2 \mu \mathrm{l})$ of the cell suspension were then dispensed onto agar-coated slides with or without a test agent, and the rate of raft movement was observed using a phase-contrast microscope $(\times 400)$ equipped with an ocular micrometer. Observations were made for up to $10 \mathrm{~min}$. Longer observation times resulted in drying of the agar and cessation of raft movement. Control cells grown in the absence of a test agent were placed onto agar-coated slides both with and without the agents. The rate of raft movement $\left(\mu \mathrm{m} \mathrm{min}^{-1}\right)$ in the presence of the agent was expressed as a percentage of the control for each time of exposure to each agent.

Measurement of respiratory activity $\left(\mathrm{O}_{2}\right.$ consumption). Overnight cultures were diluted in fresh medium and incubated until an $\mathrm{OD}_{650}$ of $0 \cdot 13-0 \cdot 2$ was obtained. Oxygen consumption was measured at room temperature (approx. $25^{\circ} \mathrm{C}$ ) with a Clark oxygen electrode (Yellow Springs Instruments) attached to a strip chart recorder. The electrode was calibrated using sodium dithionite to establish an anaerobic base line. After establishing a linear (control) rate of $\mathrm{O}_{2}$ consumption by a cell suspension, the agent to be tested was introduced into the electrode chamber and $\mathrm{O}_{2}$ consumption was monitored for 5-10 min. Respiratory rates were calculated as percentages of the control rate.

Measurement of cellular ATP. A culture was inoculated into fresh medium and incubated at $25^{\circ} \mathrm{C}$ until an $\mathrm{OD}_{650}$ of $0 \cdot 15-0.2$ was attained. (E. coli was grown to an $\mathrm{OD}_{650}$ of approximately $0 \cdot 35$. These optical densities of $E$. coli and $C$. johnsonae reflect an equivalent number of cells per $\mathrm{ml}$ ). Aliquots of the culture were placed into flasks, various test agents added and the cultures were incubated at $25^{\circ} \mathrm{C}$ for up to $30 \mathrm{~min}$. ATP was extracted from the cells by injecting $125 \mu \mathrm{l}$ of cell suspension into $2.5 \mathrm{ml}$ boiling Tris $/ \mathrm{HCl}$ buffer $(0.02 \mathrm{M}$, $\mathrm{pH} 7.75)$ in chromic acid-cleaned screw-capped tubes (Hamilton \& Holm-Hansen, 1967; Ridgway, 1977). The samples were boiled for 4-5 min to permit complete extraction of ATP, cooled to room temperature and then frozen at $-20^{\circ} \mathrm{C}$ until analysis. The ATP content was determined by the luciferase-luciferin assay procedure provided with the Lumat LB9501 Semi-automatic Lumin-ometer (EGG Berthold). ATP levels were calculated by reference to ATP standards and expressed as nmol ATP (mg dry wt cells) ${ }^{-1}$.

Measurement of intracellular volume. The internal cell volumes of the cytoplasm and periplasm were measured using the methods of Collins \& Hamilton (1976) and Stock et al. (1977). Overnight cultures were diluted in fresh medium and reincubated until an $\mathrm{OD}_{650}$ of approximately 0.4 (equivalent to approx. $0.29 \mathrm{mg}$ dry wt cells $\left.\mathrm{ml}^{-1}\right)$. E. coli was grown to an $\mathrm{OD}_{650}$ of approximately 0.75 (equivalent to approx. $0.29 \mathrm{mg}$ dry wt cells $\mathrm{ml}^{-1}$ ). The cells were harvested by centrifugation $(12000 \mathrm{~g})$ for $10 \mathrm{~min}$ at $4^{\circ} \mathrm{C}$ and the cell pellet was resuspended in $10 \mathrm{mM}$ Tris $/ \mathrm{HCl}$ buffer $(\mathrm{pH} 7 \cdot 3$ ) to a density of $10 \mathrm{mg}$ dry wt cells $\mathrm{ml}^{-1}$. Stirred cell suspensions $(10 \mathrm{mg}$ dry wt $\mathrm{ml}^{-1}$ ) were incubated with the following radiolabelled compounds for $10 \mathrm{~min}$ : $\left[\mathrm{U}^{14} \mathrm{C}\right.$ ] sucrose $/{ }^{3} \mathrm{H}_{2} \mathrm{O}$ (measurement of cytoplasmic volume); [carboxy- $\left.{ }^{14} \mathrm{C}\right]$ inulin $/{ }^{3} \mathrm{H}_{2} \mathrm{O}$ (measurement of total cell volume). Radioactivities were $\left[{ }^{14} \mathrm{C}\right]$ sucrose, $0.05 \mu \mathrm{Ci} \mathrm{l}^{-1} \quad\left(1.85 \mathrm{kBq}^{-1} \mathrm{l}^{-1}\right), \quad$ sp. act. $\quad 530 \mathrm{mCi} \mathrm{mmol}^{-1}$ $\left(19.6 \mathrm{GBq} \mathrm{mmol}^{-1}\right)$; $\left[{ }^{14} \mathrm{C}\right]$ inulin, $0.05 \mu \mathrm{Ci}^{-1} \mathrm{l}^{-1}\left(1.85 \mathrm{kBq}^{-1}{ }^{-1}\right)$, sp. act. $13 \mathrm{mCi} \mathrm{mmol}^{-1}\left(481 \mathrm{MBq} \mathrm{mmol}^{-1}\right) ;{ }^{3} \mathrm{H}_{2} \mathrm{O}$, sp. act. $0.05 \mathrm{mCi} \mathrm{ml}^{-1}\left(1.85 \mathrm{MBq} \mathrm{ml}^{-1}\right)$.

After incubation, $400 \mu \mathrm{l}$ replicate samples were taken and filtered through $0.45 \mu \mathrm{m}$ nitrocellulose membrane filters (Gelman Sciences). The samples were dried by suction for $2 \mathrm{~min}$ (but not washed) and then placed in vials containing $5 \mathrm{ml}$ scintillation cocktail (Opti-fluor, Packard Instruments). In addition, $50 \mu$ l replicate samples were taken directly from the cell suspension and placed into vials containing $5 \mathrm{ml}$ scintillation cocktail and a nitrocellulose filter disk. The vials were allowed to sit overnight at room temperature to ensure elution of the radiolabelled cells and even distribution of radioactivity from the filters. The radioactivity was then measured for 10 min using a double label program in a scintillation counter. The cell volumes were calculated using the formula described by Rottenberg (1979).

Measurement of $\Delta \mathrm{pH}$ and $\Delta \psi \cdot \Delta \mathrm{pH}(\mathrm{pH}$ gradient) was determined from the equilibrium distribution of $\left[7-{ }^{14} \mathrm{C}\right]-$ benzoic acid using flow dialysis (Ramos et al., 1979; Friedberg \& Kaback, 1980). The equilibrium distribution of benzoic acid was determined by substituting the calculated $\mathrm{pH}$ values into the Henderson-Hasselbalch equation, using $50 \mu \mathrm{M}$ benzoic acid (final concn), $\mathrm{pK} K_{\mathrm{a}}=4.19$ and an internal volume of $1.71 \mu \mathrm{l}$ (mg dry wt cells) ${ }^{-1}$. The flow dialysis cell (model H40270, Bel-Art Products) was set at a flow rate of $4.4 \mathrm{ml}$ $\mathrm{min}^{-1}$ and $1 \mathrm{ml}$ fractions were collected for measurement of radioactivity by liquid scintillation spectrometry. The upper and lower chambers of the flow dialysis cell were separated by a dialysis membrane with a molecular mass cutoff of $6000 \mathrm{Da}$ (product H40299, Bel-Art Products). The membrane was prepared by autoclaving for $15 \mathrm{~min}$ in $5 \mathrm{mM}$ EDTA (sodium salt, $\mathrm{pH} 7$ ), rinsed three times in deionized water and stored in water at $4{ }^{\circ} \mathrm{C}$ until needed. Cells were grown to $\mathrm{OD}_{650} 0 \cdot 4-0.5$, and harvested at $4^{\circ} \mathrm{C}$. Sphaeroplasts were prepared (Godchaux \& Leadbetter, 1988) and centrifuged at $2500 \mathrm{~g}$ for $5 \mathrm{~min}$. The supernatant was removed and $\mathrm{KCl}(1 \mathrm{M})$ was added to the cell pellet (final concn $100 \mu \mathrm{M}$ ) to enhance cell stability. To determine the $\Delta \mathrm{pH}$, the sphaeroplast suspension was added to the upper chamber of the flow dialysis cell (final concn $2 \mathrm{mg}$ dry wt cells $\mathrm{ml}^{-1}$ ) containing $0 \cdot 1 \mathrm{M}$ potassium phosphate buffer pH 6.0 (total volume of upper chamber, $800 \mu \mathrm{l})$. The flow was started and radioactive benzoic acid [final concn $50 \mu \mathrm{M}$, sp. act. $13.6 \mathrm{mCi} \mathrm{mmol}^{-1}(0.5 \mathrm{GBq}$ $\left.\left.\mathrm{mmol}^{-1}\right)\right]$ was added to the upper chamber. Both upper and lower chambers were mixed thoroughly with stirbars. After 25 fractions had been collected, $10 \mu \mathrm{M}$ valinomycin was added (when used), and after fraction 35 had been collected, $10 \mu \mathrm{M}$ nigericin was added. Since sphaeroplasts contained ample endogenous substrate, ascorbate and PMS were not needed as an electron donor system. Agents to be tested were added to the upper chamber with the sphaeroplast suspension prior to the addition of benzoate. The same buffer as in the upper chamber was pumped through the lower chamber (via a peristaltic pump) to a fraction collector and the radioactivity in the effluent was determined.

The electrical potential across the membrane $(\Delta \psi)$ was determined by measuring the equilibrium distribution of $\mathrm{TPP}^{+}$using flow dialysis, as described for $\Delta \mathrm{pH}$, with slight modifications. The flow rate of the buffer through the flow

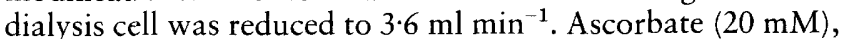
PMS $(0 \cdot 1 \mathrm{mM})$ and $\mathrm{MgSO}_{4}(10 \mathrm{mM})$ were added to the upper chamber of the flow dialysis cell containing the sphaeroplast suspension (final concn $4 \mathrm{mg}$ dry wt cells $\mathrm{ml}^{-1}$ ) in $0.2 \mathrm{mM}$ potassium phosphate buffer with $150 \mathrm{mM} \mathrm{NaCl}$ at $\mathrm{pH} 7 \cdot 5$. The flow was started and the reaction was initiated after the addition of $10 \mu \mathrm{M} \mathrm{TPP}^{+}$[sp. act. $37 \mathrm{Ci} \mathrm{mmol}^{-1}(1.4 \mathrm{TBq}$ $\left.\mathrm{mmol}^{-1}\right)$ ]. Equilibrium was established, and after 50 fractions had been collected, the appropriate concentration of agent to be tested was added. At fraction 80, 10\% Triton X-100 was added to ensure complete disruption of the cell membrane. No correction was made for binding of $\mathrm{TPP}^{+}$to the surface of the sphaeroplasts since binding was never greater than $5 \%$ of the radioactivity measured. 
Calculation of $\Delta \mathrm{pH}, \Delta \psi$ and protonmotive force $(\Delta p)$. The equilibrium distribution of solutes was calculated using the measured value of $1 \cdot 71 \mu$ internal volume (mg dry wt cells $)^{-1}$. The internal $\mathrm{pH}$ was calculated as described by Ramos et al. (1979) and the pH gradient was expressed as the difference between the internal and external $\mathrm{pH}$. This value can be converted into $\mathrm{mV}$ by substitution into the Nernst equation. The membrane potential $(\Delta \psi)$ was also calculated by substituting the equilibrium concentrations of $\mathrm{TPP}^{+}$across the membrane into the Nernst equation. The protonmotive force $(\Delta p)$ was determined by substituting the values of $\Delta \mathrm{pH}$ and $\Delta \psi$ into the equation $\Delta p=\Delta \psi-59 \Delta \mathrm{pH}$, where $\Delta \psi$ is the membrane potential in $\mathrm{mV}, \Delta \mathrm{pH}$ is the proton gradient across the membrane and $\Delta p$ is the protonmotive force expressed in $\mathrm{mV}$. The constant, 59 , in the equation equals $2.303 \mathrm{RT} / \mathrm{F}$ at $25^{\circ} \mathrm{C}$.

\section{RESULTS}

\section{Effects on colony spreading, movement of latex beads and raft movement}

Colony spreading. When diluted cell suspensions of $C$. johnsonae were plated onto solid media containing concentrations of sodium acetate ranging from 0 to $85 \mathrm{mM}$, typical colony spreading was observed up to $50 \mathrm{mM}$. However, with $50 \mathrm{mM}$ acetate, both spreading and non-spreading colonies were observed. On media containing $>65 \mathrm{mM}$ acetate, the colonies that appeared were non-spreading and the initial viable count on this medium was markedly reduced when compared to counts using media with $<50 \mathrm{mM}$ acetate. In the continuation of this study, we employed a concentration of acetate $(45 \mathrm{mM})$ at which colony spreading was normal.

Since a decrease in the electrochemical gradient in the membrane by acetate (or any of the 'energy-related' agents) could conceivably diminish the ability of cells to glide (or colonies to spread), we examined the effect of several such agents on colony spreading by incorporating increasing concentrations of them into agar medium (Table 1). We found that in addition to acetate, recognized inhibitors such as arsenate, azide and cyanide also permitted growth and colony spreading, whilst DNP, CCCP, FCCP and DCCD inhibited colony spreading at the concentrations listed (Table 1).

Movement of latex beads. Bead movement was totally inhibited on cells grown on medium containing acetate. In addition, fewer beads appeared to be bound to the surface of acetate-grown cells than noted for control cells (data not shown). Within a fraction (about onethird) of a generation time, bead movement would resume on cells that had been washed free of acetate and resuspended in broth lacking acetate. Control cells (grown in broth without acetate, then centrifuged, washed and resuspended in acetate broth) ceased to move beads within $5 \mathrm{~min}$ of exposure to acetate.

As shown in Table 1, bead movement was not observed on cells grown in the presence of FCCP, cyanide or arsenate; the number of beads bound to the cell surface was estimated to be reduced by approximately $40 \%$. Not only was bead movement stimulated in cells grown with $50 \mu \mathrm{M}$ DNP, but twice that amount did not inhibit the movement of beads on the cell surface. Bead movement continued on cells exposed to azide and CCCP even after $5 \mathrm{~h}$ of exposure to the inhibitor. When concentrations of DCCD and CCCP were increased to $15 \mu \mathrm{M}$ and $10 \mu \mathrm{M}$, respectively, bead movement stopped on control cells (grown in broth without acetate, centrifuged, washed and then suspended in broth with acetate) within $5 \mathrm{~min}$ of exposure.

Since bead movement has normally been assessed using liquid-grown cells, we sought to determine if beads could move on cells that had been grown on agar surfaces. We sought also to determine the effect that longer exposure to acetate might have on bead movement. Cells were plated on agar containing acetate, incubated for $48 \mathrm{~h}$, rinsed from the plates and resuspended in broth with and without acetate. Cells were monitored for up to $3 \mathrm{~h}$ for bead movement on their

Table 1. Inhibitors, concentrations and their effects on Cytophaga johnsonae

\begin{tabular}{|c|c|c|c|c|c|c|c|}
\hline Inhibitor & $\begin{array}{c}\text { Concn range } \\
\text { tested }\end{array}$ & $\begin{array}{l}\text { Selected } \\
\text { concn }\end{array}$ & $\begin{array}{l}\text { Generation } \\
\text { time (min) }\end{array}$ & $\begin{array}{c}\text { Bead } \\
\text { movement }^{*}\end{array}$ & $\begin{array}{c}\text { Raft } \\
\text { movement }\end{array}$ & $\begin{array}{l}\text { Spreading } \\
\text { on agar } \dagger\end{array}$ & $\begin{array}{c}\text { Presumed } \\
\text { inhibitory effect }\end{array}$ \\
\hline Acetate & $0-85 \mathrm{mM}$ & $45 \mathrm{mM}$ & 127 & - & + & $\mathrm{S}$ & Protonophore \\
\hline DNP & $5-400 \mu \mathrm{M}$ & $50 \mu \mathrm{M}$ & 115 & + & + & NS & Protonophore \\
\hline $\mathrm{CCCP}$ & $0 \cdot 1-10 \mu \mathrm{M}$ & $5 \mu \mathrm{M}$ & 180 & + & - & NS & Protonophore \\
\hline Cyanide & $1-3 \mathrm{mM}$ & $1 \mathrm{mM}$ & 360 & - & + & $S$ & Terminal oxidase \\
\hline Arsenate & $10-40 \mathrm{mM}$ & $20 \mathrm{mM}$ & 130 & - & + & $S$ & $\begin{array}{l}\text { ATPase } \\
\left(\text { competes for } \mathrm{P}_{\mathrm{i}}\right)\end{array}$ \\
\hline DCCD & $5-15 \mu \mathrm{M}$ & $10 \mu \mathrm{M}$ & 126 & + & + & NS & $\mathrm{F}_{0}$ ATPase \\
\hline
\end{tabular}

"Determined from $>20$ replicates.

$\dagger S$, growth and colony spreading; NS, growth but no spreading. 
Table 2. Rate of raft movement in the presence of inhibitors

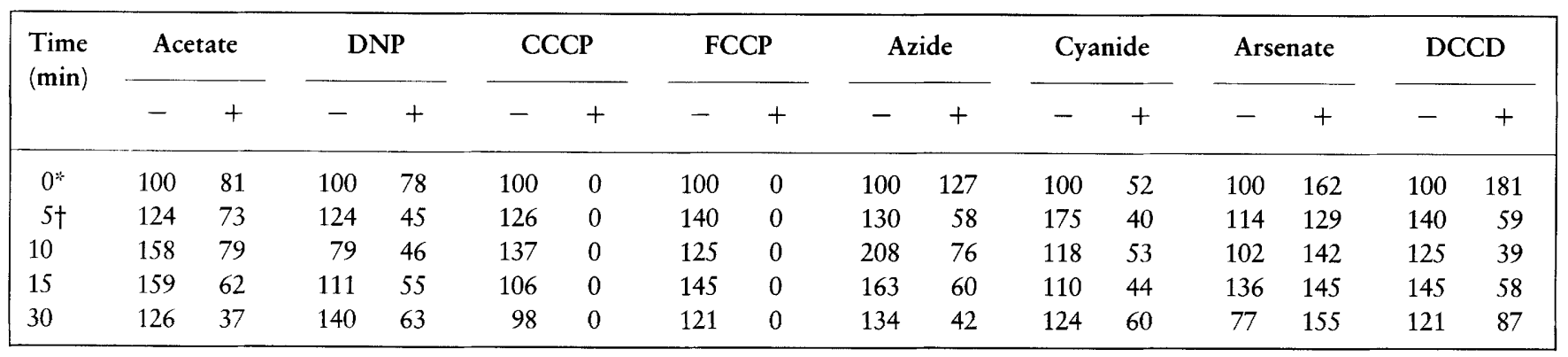

* Cells were grown in the absence of inhibitor and observed on agar with $(+)$ or without $(-)$ the inhibitor.

†Cells were grown in the presence of inhibitor and observed on agar with $(+)$ and without $(-)$ inhibitor. Data are expressed as a percentage of raft movement of control cells grown in the absence of the inhibitor and examined on agar without inhibitor. Each value represents the mean of three or more separate experiments.

surfaces. Cells grown in the absence of acetate moved beads immediately (control). However, bead movement was not observed on cells grown with acetate then placed in broth containing acetate at the same concentration. In contrast, bead movement did resume $1 \mathrm{~h}$ after cells grown on agar with acetate were resuspended in broth lacking acetate.

Ability of cells to move as rafts. The ability of cells to coalesce, and form and move as groups of cells (rafts) was assessed at various time points after exposure to each of the test agents. The rate of raft movement was calculated and expressed as a percentage of the control rate (Table 2).

Acetate had little inhibitory effect on raft movement, whilst CCCP and FCCP totally prevented raft formation. These cells were not dead; when washed free of the inhibitor, they formed rafts when deposited onto agar lacking CCCP or FCCP. In contrast, arsenate increased the rate of raft movement to well above control levels. Other agents (e.g. DNP, azide, cyanide) decreased the rate of raft movement to approximately $50 \%$ of the control rate. An initial decrease in raft movement was noted at $5 \mathrm{~min}$ but little change occurred in the ensuing $30 \mathrm{~min} . \mathrm{NaCl}$ was used in this particular set of experiments as an additional salt control (osmolyte). No significant difference in the rate of raft formation was observed in the presence of $50 \mathrm{mM} \mathrm{NaCl}$ (data not shown).

\section{Effects on $\mathrm{O}_{2}$ consumption}

Fig. 1(a) illustrates the effect that the various compounds tested had on the rate of $\mathrm{O}_{2}$ consumption in C. johnsonae at $25^{\circ} \mathrm{C}$. Most slowed the rate of $\mathrm{O}_{2}$ consumption (CCCP, FCCP, azide, cyanide) or had little or no effect (arsenate, DCCD).

Although CCCP and FCCP presumably act to disrupt the membrane potential, as well as to uncouple oxidative phosphorylation, they decreased the $\mathrm{O}_{2}$ consumption by only $26 \%$ and $37 \%$, respectively, at the concentrations tested. Azide and cyanide dramatically decreased $\mathrm{O}_{2}$ consumption by $\geqslant 85 \%$. The apparent stimulation of respiratory activity by acetate and DNP was not statistically significant (Kruskal-Wallis test of significance).

Since the effects of these agents on C. jobnsonae were in some instances surprising, we assessed their effects (at the concentrations employed for C. johnsonae) on $E$. coli grown at $37^{\circ} \mathrm{C}$ and $25^{\circ} \mathrm{C}$ (Fig. 1b). Clearly the effects of the agents on C. johnsonae and E. coli were not identical for each agent. At the concentrations tested, the agents decreased $\mathrm{O}_{2}$ utilization in E. coli; an exception was arsenate, which had no effect at $25^{\circ} \mathrm{C}$ but produced a $13 \%$ stimulation at $37^{\circ} \mathrm{C}$. DCCD, which had no effect on C. johnsonae, did affect E. coli, leading to a decrease in $\mathrm{O}_{2}$ consumption of $60 \%$. While $\mathrm{O}_{2}$ consumption in E. coli at $37^{\circ} \mathrm{C}$ was inhibited approximately $32 \%$ by acetate and $42 \%$ by $\mathrm{DNP}, \mathrm{O}_{2}$ consumption was not affected in C. jobnsonae by either compound at the concentrations employed.

\section{Effect on cellular ATP content}

Fig. 2 illustrates the effects of the various agents on the total cellular ATP in growing cultures of C. jobnsonae when exposed for up to $30 \mathrm{~min}$. The optical densities were measured at the start and finish of the experiment for the purpose of monitoring growth over the $30 \mathrm{~min}$ test period. The initial $\mathrm{OD}_{650}$ was $0 \cdot 17$. Optical densities were greater at termination than at the onset of the experiment (thus confirming growth), with the exceptions of cultures containing DNP $\left(\mathrm{OD}_{650} \quad 0 \cdot 22\right)$, $\mathrm{DCCD}$ and azide (both $\mathrm{OD}_{650} 0 \cdot 20$ ), where growth was seriously affected by the action of the various inhibitors. Not surprisingly, the most potent inhibitors appeared to be cyanide and arsenate.

Fig. 2(a) demonstrates the effect of protonophores presumed to act on C. johnsonae by inducing a proton flux in the membrane by rendering it 'leaky' to protons. As a result, the membrane would not have been able to maintain a proton gradient; ATP can still be produced, but not as efficiently. Cultures to which CCCP, FCCP or acetate were to be added contained 2.34, 2.40 and $2.23 \mathrm{nmol}$ ATP (mg dry wt cells) ${ }^{-1}$, respectively. After 
(a)

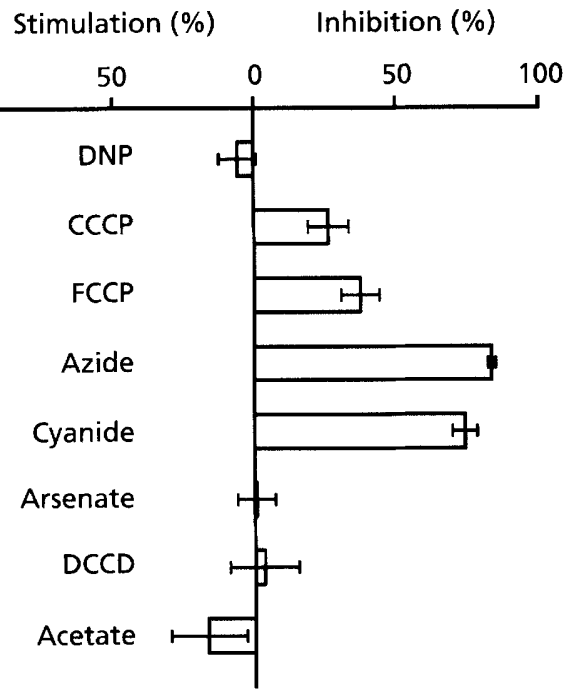

(b)

$$
\text { Stimulation (\%) Inhibition (\%) }
$$

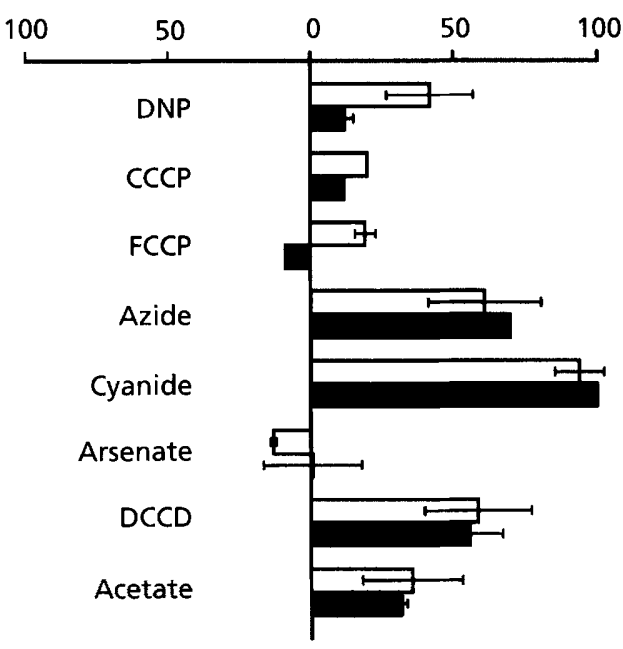

Fig. 1. Effect of inhibitors of electron transport and oxidative phosphorylation on $\mathrm{O}_{2}$ consumption. Each bar represents the mean of three values and was compared to a control consisting of cells in the same medium without inhibitor. The error bars represent the standard error of the mean. (a) $\mathrm{O}_{2}$ consumption by $C$. johnsonae grown at $25^{\circ} \mathrm{C}$; (b) $\mathrm{O}_{2}$ consumption by $\mathrm{E}$. coli grown at $37^{\circ} \mathrm{C}$ (open bars) and $25^{\circ} \mathrm{C}$ (filled bars).

30 min exposure to the test agent, the ATP levels were dramatically reduced $[0.91,1.10$ and $0.71 \mathrm{nmol}$ ATP mg (dry wt cells) ${ }^{-1}$, respectively]. Although its mode of action is thought to be the same as the above agents, DNP had little effect on total cellular ATP. Initial values of $2.28 \mathrm{nmol}$ ATP ( $\mathrm{mg}$ dry wt cells) $)^{-1}$ and final values of $2 \cdot 23 \mathrm{nmol}$ ATP (mg dry wt cells) ${ }^{-1}$ were seen with DNP, as compared to control values of 2.34 and $3.40 \mathrm{nmol}$ ATP (mg dry wt cells) ${ }^{-1}$, respectively.

Fig. 2(b) displays the effect of inhibitors of terminal oxidase (azide, cyanide) and of ATPase (DCCD, arsenate, azide) on ATP production in cells. Most pro-
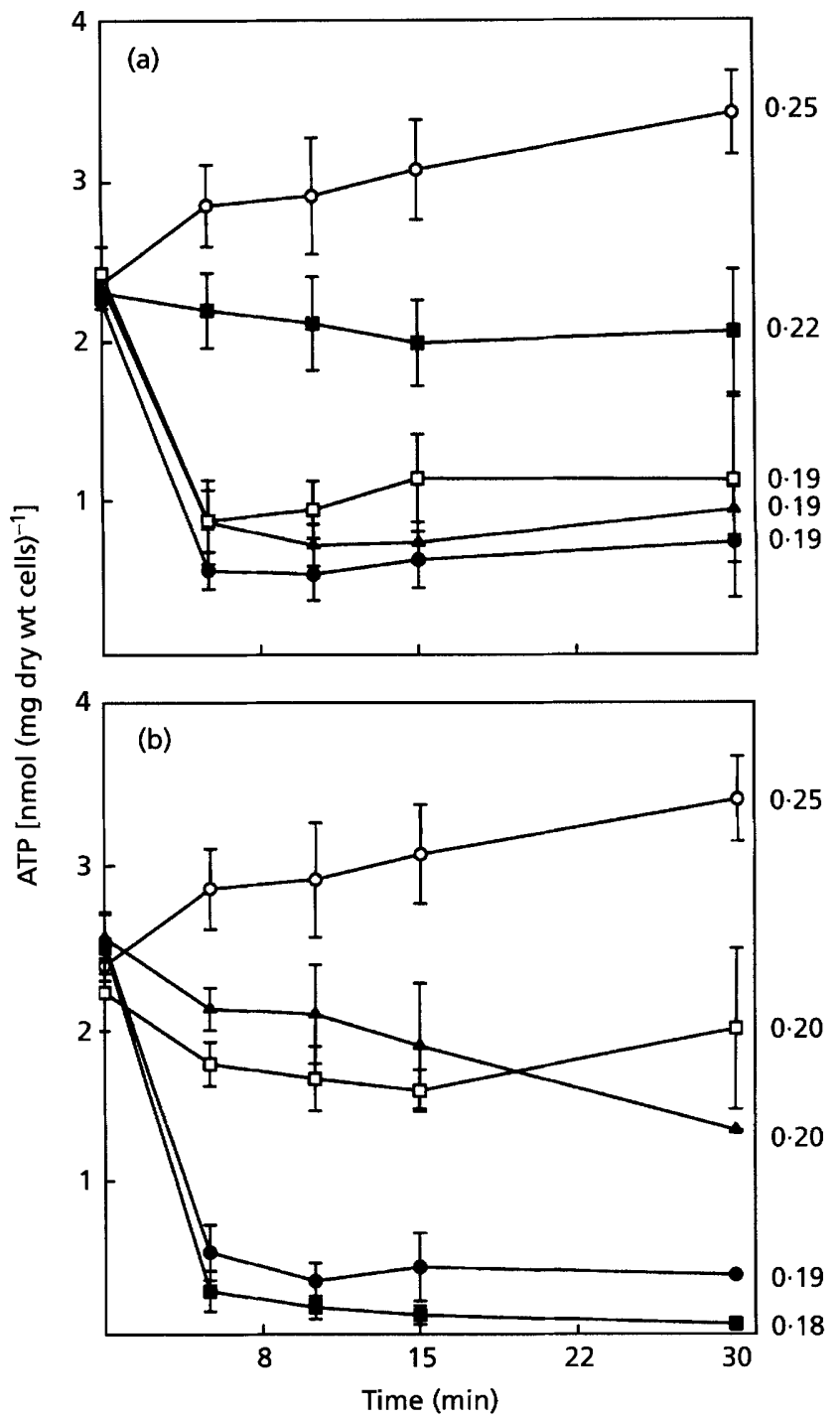

Fig. 2. Mean total ATP concentration in C. johnsonae cells after addition of (a) various protonophores and (b) various ATPase and terminal oxidase inhibitors. Each value represents three or more individual assessments. The error bars represent the standard error of the means. The optical density of the culture was determined before the onset of the assay and was adjusted to $\mathrm{OD}_{650} 0.17$ (zero time). Final optical densities were measured at the termination of the assay $(30 \mathrm{~min})$ and are indicated at the right of the graph. (a) $\bigcirc$, Control; $\square, F C C P ; 0$, acetate; $\square$ DNP; $\triangle$, CCCP. (b) $O$, Control; $\square$, DCCD; 0 , arsenate; cyanide; $\boldsymbol{\Lambda}$, azide.

nounced is the effect of cyanide on ATP production. Even though the ATP pool at the onset was $2.46 \mathrm{nmol}$ ( $m$ g dry wt cells $)^{-1}$, the effect of cyanide was immediate and nearly complete, resulting in only $0.08 \mathrm{nmol}$ ATP (mg dry wt cells) ${ }^{-1}$ after a $30 \mathrm{~min}$ exposure. Interestingly, azide, also an inhibitor of terminal oxidases as well as an inhibitor of the $F_{1}$ subunit of ATPase, did not have as profound an effect as cyanide. The initial ATP value with azide was $2.51 \mathrm{nmol}(\mathrm{mg} \text { dry wt cells })^{-1}$, but fell only to $1.31 \mathrm{nmol}(\mathrm{mg} \text { dry wt cells })^{-1}$, slightly less than one-third that of the control, within the $30 \mathrm{~min}$ 
Table 3. Summary of the effect of inhibitors on $\Delta \mathrm{pH}, \Delta \psi$ and $\Delta p$ of Cytophaga johnsonae

\begin{tabular}{|lcccc|}
\hline Inhibitor & \multicolumn{2}{c}{$\Delta \mathbf{p H}^{*}$} & $\begin{array}{c}\Delta \boldsymbol{\psi} \dagger \\
(\mathbf{m V})\end{array}$ & $\begin{array}{c}\Delta \boldsymbol{p} \neq \\
(\mathbf{m V})\end{array}$ \\
\cline { 2 - 4 } & at pH $\mathbf{6 . 0}$ & at $\mathbf{p H ~ 7 \cdot 5}$ & & \\
\hline None & $1 \cdot 4 \pm 0 \cdot 14$ & 0 & $-130 \pm 18$ & -130 \\
Acetate & 0 & 0 & $-101 \pm 15$ & -101 \\
DNP & 0 & 0 & $-80 \pm 15$ & -80 \\
CCCP & 0 & 0 & $-104 \pm 5$ & -104 \\
Azide & $0 \cdot 78 \pm 0 \cdot 14$ & $0 \cdot 72$ & -119 & -161 \\
Cyanide & 0 & 0 & $-110 \pm 4$ & -110 \\
Arsenate & $0 \cdot 96 \pm 0 \cdot 20$ & $0 \cdot 54$ & $-94 \pm 9$ & -126 \\
DCCD & $0 \cdot 75 \pm 0 \cdot 14$ & $0 \cdot 75$ & $-83 \pm 7$ & -127 \\
\hline
\end{tabular}

*Determined in $0 \cdot 1 \mathrm{M}$ phosphate buffer.

†Determined in $0.2 \mathrm{mM}$ phosphate buffer at $\mathrm{pH} 7 \cdot 5$.

$\mp$ Values given are for cells growing at $\mathrm{pH} 7 \cdot 5$. FCCP was used to dissipate the membrane potential with the control cells.

exposure. Azide treatment decreased the ATP content from 2.5 to $1.31 \mathrm{nmol}(\mathrm{mg} \text { dry wt cells })^{-1}$ within $30 \mathrm{~min}$ exposure. Arsenate, which is a competitor of the phosphorylation of ADP to ATP, reduced ATP levels from 2.48 to $0.39 \mathrm{nmol}$ ATP (mg dry wt cells) ${ }^{-1}$. DCCD, an inhibitor of the $F_{0}$ subunit of ATPase, initially decreased ATP production at a steady rate, but after 15 min ATP levels began to rise gradually. This unexpected rise in ATP levels was reproducible. In the control, the optical density as well as the concentration of ATP was increased.

\section{Effect of inhibitors on $\Delta \mathrm{pH}$ and $\Delta \psi$}

Calculations based upon the equilibrium distribution of benzoic acid using flow dialysis before and after the addition of valinomycin indicated an internal $\mathrm{pH}$ of $7 \cdot 45$ and $7 \cdot 63$, respectively (plot not shown). The $\Delta \mathrm{pH}$ without valinomycin was $1.45 \mathrm{pH}$ units $(7.45$ inside, 6.0 outside), and the $\Delta \mathrm{pH}$ with valinomycin was $1.63 \mathrm{pH}$ units $(7.63$ inside, 6.0 outside). When substituted into the Nernst equation, these values before and after the addition of valinomycin corresponded to $86 \mathrm{mV}$ and $97 \mathrm{mV}$, respectively.

As expected, the proton gradient was collapsed by the protonophores DNP, CCCP and FCCP, resulting in a $\mathrm{pH}_{\text {in }}$ equal to the $\mathrm{pH}_{\text {out }}($ Table 3$)$. Acetate $(45 \mathrm{mM})$ also acted as a protonophore by collapsing the proton gradient. However, at concentrations of acetate $\leqslant 10$ $\mathrm{mM}$, a small $\Delta \mathrm{pH}$ was observed (data not shown). Cyanide, although not considered a protonophore, also collapsed the proton gradient. Cells exposed to azide, arsenate and DCCD maintained a slight proton gradient, with $\mathrm{pH}_{\text {in }}$ of $6.78,6.96$ and 6.75 , respectively.

Using flow dialysis procedures similar to those described for $\Delta \mathrm{pH}, \Delta \psi$ was determined by measuring the equilibrium distribution of the lipophilic cation, $\mathrm{TPP}^{+}$.
Addition of some test agents resulted in a rapid release of $\mathrm{TPP}^{+}$from the cell interior, presumably as a result of the loss of the electrical potential in the membrane. Control cells maintained a $\Delta \psi$ of $-130 \mathrm{mV}$, as shown in Table 3 , and other agents lowered the $\Delta \psi$ only modestly.

\section{DISCUSSION}

The results of the present study supply new evidence that the ability of cells of C. johnsonae to move beads over their surface is not necessarily correlated with the mechanics of gliding and colony spreading. Although acetate is unable to serve as a sole source of carbon and energy for growth of this bacterium, when supplied at nutrient-level concentrations this compound stopped bead movement on bacterial surfaces without completely inhibiting either raft formation or movement or typical colony spreading on the agar-solidified medium. The basis for this differential inhibition of bead movement and cell migration, two events which many assume to be causally related, has been a focus of this report. We compared the effects of acetate, a weak acid and recognized protonophore, with the effects of several chemicals considered to interfere with energy production in cells (i.e. electron transport or protonmotive force).

The ability of the cytophagas to move latex spheres over their cell surface is not an ability widespread among prokaryotes. Accordingly, the observations that certain mutant cytophagas unable to move beads were also unable to glide (Pate \& Chang, 1979) led to the suggestions (see also Lapidus \& Berg, 1982) that bead movement was a reflection of the operation of the motility machinery responsible for cell migration. This attractive relationship has, however, been considered tenuous (Ridgway \& Lewin, 1988; Gorski et al., 1991) as a result of additional studies. We conclude, on the basis of separate studies, that the ability of this 
bacterium to move beads over its surface is not a necessary correlate of cell migration with the resultant formation and movement of rafts of cells and the formation of thin, uneven-edged spreading colonies characteristic of this gliding bacterium.

The results presented here support the notion that the existence of a membrane potential, rather than ATP per se, supplies the energy for prokaryotic gliding motility (e.g. Pate \& Chang, 1979; Ridgway, 1977; Chailakhyan et al., 1982; Glagoleva et al., 1980). They also suggest that ATP content has a more significant effect on bead movement than does the protonmotive force. The magnitude of differences in protonmotive force between control cells and those treated with test agents is minimal and accordingly seems unlikely to account for the inhibition of bead movement. In contrast, cell motility was little affected by those compounds that both stopped bead movement and brought about a pronounced decrease in cell ATP content.

It is important to note that assumptions about the effects of various classical inhibitory agents on $C$. jobnsonsae may be imprecise, largely because of the concentrations employed (those that permitted growth of the bacterium, rather than the usually higher concentrations employed in studies of other organisms in which growth was notably altered), and because assessment of effects on bead movement are short-term, while effects on raft movement and colony spread are measured over considerably longer time periods. Another necessary caveat is based on the profound differences between the chemical composition of the outer membrane of this bacterium and that of many other Gram-negative cells (Godchaux \& Leadbetter, 1988; Pitta et al., 1989), particulary in lipid composition and membrane protein profiles. One indication of the impact of these differences is reflected in the unusual inhibition of growth of gliding bacteria by actinomycin $D$, a sensitivity unusual among Gram-negative bacteria (Dworkin, 1969). Clearly, the actions of agents tested in this study may not be those reported for other well-studied organisms. However, any uncertainty of the actual mode of action(s) does not diminish the significance of the differential effects noted on bead movement and cell migration.

Until a definitive understanding of the mechanism(s) and machinery involved in gliding motility becomes available, any significance of the small differences noted in protonmotive force between cells grown in the presence or absence of acetate or the 'metabolic' inhibitors remains a matter of speculative interpretation. This is also the case for any relationships between bead movement and cell motility; although these do not seem to be equivalent processes, it is possible that they may share some common machinery, as has also been suggested by Gorski et al. (1991).

\section{ACKNOWLEDGEMENTS}

This research was supported by grant MCB-9220647 from the National Science Foundation. We also thank Robert Veith of the Biotechnology Center at the University for his time and technical assistance in the determination of ATP, and Professors Eva Kashket and Judith Armitage for helpful comments.

\section{REFERENCES}

Abbanat, D. R., Leadbetter, E. R., Godchaux, W., III \& Escher, A. (1986). Sulfonolipids are molecular determinants of gliding motility. Nature 324, 367-369.

Chailakhyan, L. M., Glagolev, A. N., Glagolev, T. N., Murvanidze, G. V., Potapova, T. V. \& Skulachev, V.P. (1982). Intercellular power transmission along trichomes of cyanobacteria. Biochim Biophys Acta 679, 60-67.

Collins, S.H. \& Hamilton, W. A. (1976). Magnitude of the protonmotive force in respiring Staphylococcus aureus and Escherichia coli. J Bacteriol 126, 1224-1231.

Duxbury, T., Humphrey, B. A. \& Marshall, K. C. (1980). Continuous observations of bacterial gliding motility in a dialysis microchamber: the effects of inhibitors. Arch Microbiol 124, 169-175.

Dworkin, M. (1969). Sensitivity of gliding bacteria to actinomycin D. J Bacteriol 98, 851-852.

Friedberg, I. \& Kaback, H. R. (1980). Electrochemical proton gradient in Micrococcus lysodeikticus cells and membrane vesicles. J Bacteriol 142, 651-658.

Glagoleva, T. N., Glagolev, A. N., Gusev, M. V. \& Nikitina, K. A. (1980). Protonmotive force supports gliding in cyanobacteria. FEBS Lett 117, 49-53.

Godchaux, W., III \& Leadbetter, E. R. (1983). Unusual sulfonolipids are characteristic of the Cytophaga-Flexibacter group of gliding bacteria. J Bacteriol 153, 1238-1246.

Godchaux, W., III \& Leadbetter, E. R. (1988). Sulfonolipids are localized in the outer membrane of the gliding bacterium Cytophaga johnsonae. Arch Microbiol 150, 42-47.

Godchaux, W., III, Gorski, L. \& Leadbetter, E. R. (1990). Outer membrane polysaccharide deficiency in two nongliding mutants of Cytophaga johnsonae. J Bacteriol 172, 1250-1255.

Godchaux, W., III, Lynes, M. A. \& Leadbetter, E. R. (1991). Defects in gliding motility in mutants of Cytophaga johnsonae lacking a high-molecular-weight cell surface polysaccharide. J Bacteriol 173, 7607-7614.

Gorski, L., Leadbetter, E. R. \& Godchaux, W., III (1991). Temporal sequence of trait recovery during phenotypic curing of a Cytophaga johnsonae motility mutant. J Bacteriol 173, 7534 7539.

Hamilton, R. D. \& Holm-Hansen, O. (1967). Adenosine triphosphate content of marine bacteria. Limnol Oceanogr 12, 319-324.

Lapidus, I. R. \& Berg, H. C. (1982). Gliding motility of Cytophaga sp. strain U67. J Bacteriol 151, 384-398.

Nichols, P., Stulp, B. K., Jones, J. G. \& White, D. C. (1986). Comparison of fatty acid content and DNA homology of the filamentous gliding bacteria Vitreoscilla, Flexibacter, Filibacter. Arch Microbiol 146, 1-6.

Pate, J. L. \& Chang, L.-Y. E. (1979). Evidence that gliding motility in procaryotic cells is driven by rotary assemblies in the cell envelopes. Curr Microbiol 2, 59-64.

Pate, J. L. \& Ordal, E. J. (1967). The fine structure of Chondrococcus columnaris. I. Structure and formation of mesosomes. $J$ Cell Biol 35, 1-13. 
of ornithine amino lipid content in a sulfonolipid-deficient mutant of Cytophaga johnsonae. J Bacteriol 171, 952-957.

Ramos, S., Schuldiner, S. \& Kaback, H. R. (1979). Use of flow dialysis for determination of $\Delta \mathrm{pH}$ and active transport. Methods Enzymol 55, 680-688.

Ridgway, H. F. (1977). Source of energy for gliding motility in Flexibacter polymorphus: effects of metabolic and respiratory inhibitors on gliding movement. J Bacteriol 131, 544-556.

Ridgway, H. F. \& Lewin, R. A. (1988). Characterization of gliding motility in Flexibacter polymorphus. Cell Motil Cytoskeleton 11, $46-63$.

Rottenberg, H. (1979). The measurement of membrane potential and $\Delta \mathrm{pH}$ in cells, organelles, and vesicles. Methods Enzymol 55, 547-569.

Stock, J. B., Rauch, B. \& Roseman, S. (1977). Periplasmic space in
Salmonella typhimurium and Escherichia coli. J Biol Chem 252, 7850-7862.

Walker, R. W. (1968). Cis-11-hexadecenoic acid from Cytophaga butchinsonii lipids. Lipids 4, 15-18.

Ware, J. C. \& Dworkin, M. (1973). Fatty acids of Myxococcus xanthus. J Bacteriol 115, 253-261.

Weibull, C. (1960). Movement. In The Bacteria, vol. I, pp. 153-205. Edited by I. C. Gunsalus \& R. Y. Stanier. New York: Academic Press.

Wolkin, R. H. \& Pate, J. L. (1986). Phage adsorption and cell adherence are motility-dependent characteristics of the gliding bacterium Cytophaga jobnsonae. J Gen Microbiol 132, 355-367.

Received 10 June 1997; accepted 30 June 1997. 